\title{
MENINGKATKAN KEMAMPUAN MEMBACA SUKU KATA MENGGUNAKAN MODIFIKASI PERMAINAN KARTU DOMINO PADA TUNAGRAHITA SEDANG
}

\author{
IMPROVING ABILITY TO READ THE WORD USING MODIFICATION OF DOMINO \\ CARD GAMES ON TUNAGRAHITA
}

\author{
Irine Puspita \\ Sekolah Luar Biasa Negeri Subang, Indonesia \\ irine1973@yahoo.com
}

\begin{abstract}
ABSTRAK
Tujuan penelitian ini yaitu mengetahui keterbatasan peserta didik tunagrahita sedang kelas VII SMPLB-C1 dalam membaca yang membuat pencapaian beberapa kompetensi pelajaran Bahasa Indonesia dan juga pelajaran lain menjadi tertunda. IQ peserta didik tunagrahita sedang berada pada level 35-40 sampai 50-55. Mereka memiliki kesulitan pada mata pelajaran membaca. Proses membaca permulaan yang diperlukan peserta didik adalah proses recording dan decoding. Peserta didik akan menunjukkan suku kata yang dilihat kemudian mengasosiasikan dalam bunyi bahasa sesuai suku kata yang dilihat dalam rangkaian grafis dua huruf (konsonan dan vokal). Kartu domino yang digunakan merupakan kartu domino yang dimodifikasi. Teknik permainannya hampir sama, perbedaannya terletak pada simbol yang digunakan. Penelitian tindakan kelas ini dilaksanakan dalam tiga siklus dengan empat peserta didik tunagrahita sedang kelas VII SMPLB-C1 sebagai subjek penelitian. Kegiatan dilaksanakan pada semester II tahun ajaran 2015/2016. Hasil yang diperoleh menunjukkan, bahwa permainan kartu domino berhasil meningkatkan kemampuan belajar membaca suku kata pada peserta didik kelas VII SMPLB-C1. Untuk itu disarankan agar guru membuat alat peraga pendidikan yang bermakna bagi peserta didik tunagrahita sedang.

Kata Kunci: Suku Kata, Kartu Domino, Tunagrahita Sedang
\end{abstract}

\section{ABSTRACT}

The purpose of this research is to know the inability to read of seventh grade students of SMPLB-CI who have moderate mental retardation disorder made achievement of some competences in Indonesian study and the other studies were hampered. The moderate mental retardation students are those with IQs of about 35-40 until 50-55. They have difficulties in reading lessons. The first reading process that is needed are recording and decoding. The students would show the syllables which was looked then associate it in speech sound according to the syllables which was they looked in two-letter graphic series (consonant and vocal). The domino cards which was used is the modified domino cards. Technically as same playing domino card game as usual, the difference is only on the symbol that was used. This Classroom Action Research was conducted in three cycles with four seventh grade students of SMPLB-CI who have moderate mental retardation disorder as research subject. The research was carried out on semester 2 of 2015/2016 academic year. The result showed that the modified domino card game successfully improved reading syllables ability of seventh grade students of SMPLB-CI. Based on the findings of the research, it is suggested to teachers to make benefit and educated props for moderate mental retardation students.

Keyword: syllables, domino card game, mental retardation.

\section{PENDAHULUAN}

Membaca merupakan salah satu kompetensi dasar dalam mata pelajaran Bahasa Indonesia yang disajikan dalam aktivitas pembelajaran tematik. Sejak berada dalam satuan pendidikan SDLB, peserta didik tunagrahita sedang sudah mendapat pengetahuan untuk menguasai kompetensi membaca. Namun keterbatasan daya ingat pada peserta didik tunagrahita sedang membuat mereka mengalami kesulitan beraktivitas dalam membaca. Hal lain yang juga disadari adalah kemampuan dasar membaca yang sangat minim pada peserta didik. Peserta didik tunagrahita sedang kelas VII baru memahami simbol huruf vokal (a, i, u) dan satu huruf konsonan (b).

Keterbatasan peserta didik tunagrahita sedang kelas VII SMPLB-C1 dalam membaca membuat pencapaian beberapa 
kompetensi pelajaran Bahasa Indonesia dan juga pelajaran lain menjadi tertunda. Membaca merupakan salah satu kemampuan yang harus dimiliki peserta didik agar mereka dapat memahami pengetahuan lain lebih optimal. Keterbatasan daya ingat pada peserta didik tunagrahita sedang, menjadi interaksi kegiatan membaca harus diurai dari latihan membaca yang paling dasar. Mulai dari mengenal huruf vokal, huruf konsonan, suku kata, kata, kemudian kalimat. Seluruh kegiatan memerlukan waktu yang lama, dan harus dilaksanakan secara berulang-ulang.

Kegiatan membaca untuk peserta didik tunagrahita sedang selain memerlukan waktu yang lama dan memerlukan pengulangan, juga memerlukan aktivitas pembelajaran yang menyenangkan. Aktivitas membaca di kelas dapat dikelola dalam sebuah permainan. Permainan sederhana yang memberi semangat baru bagi peserta didik tunagrahita sedang, yang dapat menumbuhkan kesenangan saat bermain dan belajar. Permainan merupan salah satu hal yang banyak diminati anakanak yang memiliki keterbatasan akademik. Melalui permainan yang sederhana mereka tanpa disadari telah masuk dalam aktivitas pembelajaran yang dikelola guru.

Keterbatasan daya ingat dan kemampuan dasar yang minim dimiliki peserta didik tunagrahita sedang menjadikan permainan domino diharapkan sebagai salah satu solusi dalam aktivitas membaca pada penelitian ini. Pemilihan kartu domino dalam memecahkan permasalahan membaca suku kata di kelas VII SMPLB-C1 dilakukan karena peserta didik memiliki ketertarikan pada permainan kartu. Beberapa kartu permainan sering terlihat menarik untuk mereka simpan. Untuk itu desain warna pada kartu juga dipilih yang dapat memberikan ketertarikan kepada peserta didik.

Berdasarkan keadaan tersebut, maka permasalahan penelitian yang dirumuskan adalah: "Apakah kemampuan membaca suku kata dapat meningkat menggunakan modifikasi permainan kartu domino pada peserta didik tunagrahita sedang kelas VII SMPLB-C1 di SLB Negeri Subang?”.

Tunagrahita adalah istilah yang digunakan untuk menyebut anak yang mempunyai kemampuan intelektual di bawah rata-rata (Somantri, 2006). Istilah anak tunagrahita menurut American Association on Mental Deficiency (Grossman (Kirk \& Gallagher), 1986: 116) mengacu pada "fungsi intelek umum yang nyata berada di bawah ratarata bersama dengan kekurangan dalam adaptasi tingkah laku dan berlangsung dalam masa perkembangan". IQ anak tunagrahita diklasifikasikan berdasarkan hal berikut ini (Astati \& Lis, 2011).

1. Mild (Ringan) pada level 50 - 55 sampai 70.

2. Moderate (Sedang) pada level $35-40$ sampai $50-55$.

3. Severe-Profound (Berat-Sangat Berat) pada level 20 - 25 sampai dengan 35 40.

Peserta didik tunagrahita sedang dalam penelitian ini memiliki IQ berada pada level 35 - 40 sampai 50 - 55. Umumnya pada keadaan tersebut, peserta didik tunagrahita sedang memiliki kesulitan pada mata pelajaran membaca, menulis, dan berhitung. Sebagaimana dinyatakan oleh (Somantri, 2006) bahwa, "Anak tunagrahita sedang sangat sulit bahkan tidak dapat belajar secara akademik." Walaupun mereka dapat menulis secara sosial, misalnya menulis nama sendiri, alamat rumah, dan lainnya yang bersifat sangat sederhana. 
Membaca pada hakikatnya adalah suatu yang rumit yang melibatkan banyak hal, tidak hanya sekedar melafalkan tulisan, tetapi juga melibatkan aktivitas visual, berpikir, psikolingustik, dan meta kognitif. Sebagai proses visual, membaca merupakan proses menerjemahkan simbol tulis (huruf) ke dalam kata-kata lisan (Rahim, 2007).

Proses membaca yang ditekankan pada kegiatan penelitian ini adalah membaca permulaan untuk suku kata "ba, bi, dan bu". Proses membaca permulaan yang diperlukan peserta didik adalah proses recording dan decoding. Peserta didik akan menunjukkan suku kata yang dilihat kemudian mengasosiasikan dalam bunyi bahasa sesuai suku kata yang dilihat dalam rangkaian grafis dua huruf (konsonan dan vokal).

Kartu domino ini merupakan kartu domino yang dimodifikasi. Teknik permainannya hampir sama, perbedaannya terletak pada simbol yang digunakan. Simbol bulatan dirubah menjadi suku kata dan warna dasar. Kartu domino yang dibuat adalah kartu suku kata (ba, bi, bu) dengan rancangan desain yang dibuat sendiri oleh peneliti sebagai berikut ini.

1. Satu set kartu domino terdiri dari 9 (sembilan) model kartu, yang masingmasing model terdiri dari 6 (enam) kartu.

2. Kartu model pertama memiliki desain warna biru dan suku kata "ba".

3. Kartu model kedua memiliki desain warna kuning dan suku kata "bi".

4. Kartu model ketiga memiliki desain warna merah dan suku kata "bu".

5. Kartu model keempat memiliki desain warna biru dan warna kuning.

6. Kartu model kelima memiliki desain warna biru dan warna merah.

7. Kartu model keenam memiliki desain warna merah dan warna kuning.

8. Kartu model ketujuh memiliki desain suku kata "ba" dan suku kata "bi".

9. Kartu model kedelapan memiliki desain suku kata "ba" dan "bu".

10. Kartu model kesembilan memiliki desain suku kata "bu" dan "bi".

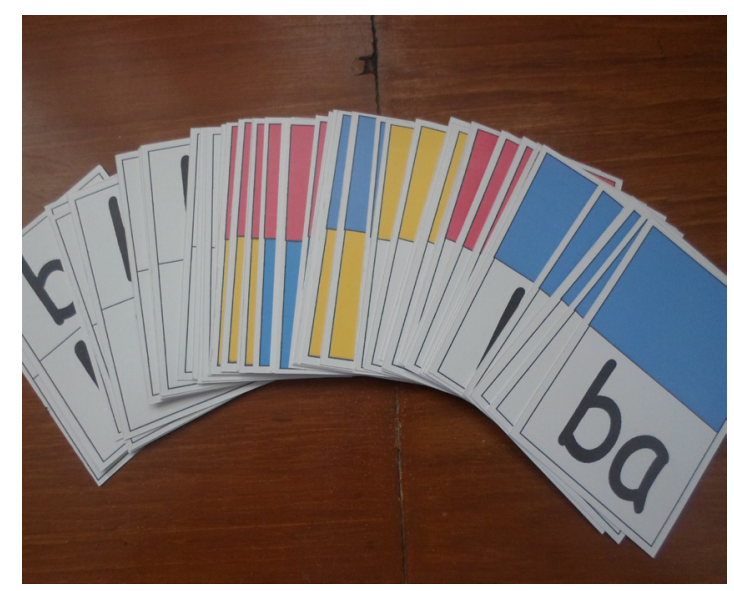

Gambar 1. Kartu Domino Suku Kata

Teknik permainan kartu domino (gambar 1) juga dirancang sendiri oleh peneliti. Permainan pertama dimulai dari suku kata "ba" dan "bi" atau kartu biru dan kartu kuning. Maka kartu model pertama, kedua, keempat, dan ketujuh akan dimainkan secara bersama-sama. Kartu dikumpulkan dan disusun untuk dikocok. Peserta didik akan bersepakat lebih dahulu untuk menentukan siapa yang mendapat giliran mengocok pertama. Setelah dikocok, kartu dibagikan kepada seluruh peserta secara rata. Setiap peserta (empat orang) akan mendapat empat kartu yang disimpan secara tertutup. Kartu sisa akan disimpan di depan kelompok yang sedang bermain kartu secara terbalik. Kartu yang tersimpan paling atas akan dibuka pertama kali sebagai kartu kunci. Maka peserta yang pertama mengocok kartu akan mendapat giliran pertama mengeluarkan kartu yang dapat dihubungkan dengan kartu 
kunci. Jika yang keluar sebagai kartu kunci adalah kartu model pertama, maka pemain harus dapat menghubungkan salah satu sisi kartu kunci dengan salah satu sisi kartu pemain. Kartu terus berjalan hingga seluruh kartu habis. Pada saat kartu dijatuhkan dan dihubungkan dengan salah satu sisi kartu yang sudah jatuh, maka pemain harus dapat menyerukan suku kata atau warna yang akan dipasangkan dengan suara keras.

Permainan kartu domino kedua dimulai dari suku kata "ba" dan "bu" atau kartu biru dan kartu merah. Maka kartu model pertama, ketiga, kelima, dan kedelapan akan dimainkan secara bersama-sama. Kartu dikumpulkan dan disusun untuk dikocok. Peserta didik akan bersepakat lebih dahulu untuk menentukan siapa yang mendapat giliran mengocok pertama. Setelah dikocok, kartu dibagikan kepada seluruh peserta secara rata. Setiap peserta (empat orang) akan mendapat empat kartu yang disimpan secara tertutup. Kartu sisa akan disimpan di depan kelompok yang sedang bermain kartu secara terbalik. Kartu yang tersimpan paling atas akan dibuka pertama kali sebagai kartu kunci. Maka peserta yang pertama mengocok kartu akan mendapat giliran pertama mengeluarkan kartu yang dapat dihubungkan dengan kartu kunci. Jika yang keluar sebagai kartu kunci adalah kartu model pertama, maka pemain harus dapat menghubungkan salah satu sisi kartu kunci dengan salah satu sisi kartu pemain. Kartu terus berjalan hingga seluruh kartu habis. Pada saat kartu dijatuhkan dan dihubungkan dengan salah satu sisi kartu yang sudah jatuh, maka pemain harus dapat menyerukan suku kata atau warna yang akan dipasangkan dengan suara keras.

Permainan kartu domino ketiga dimulai dari suku kata "bu" dan "bi" (gambar 2) atau kartu merah dan kartu kuning. Maka kartu model kedua, ketiga, keenam, dan kesembilan akan dimainkan secara bersama-sama. Kartu dikumpulkan dan disusun untuk dikocok. Peserta didik akan bersepakat lebih dahulu untuk menentukan siapa yang mendapat giliran mengocok pertama. Setelah dikocok, kartu dibagikan kepada seluruh peserta secara rata. Setiap peserta (empat orang) akan mendapat empat kartu yang disimpan secara tertutup. Kartu sisa akan disimpan di depan kelompok yang sedang bermain kartu secara terbalik. Kartu yang tersimpan paling atas akan dibuka pertama kali sebagai kartu kunci. Maka peserta yang pertama mengocok kartu akan mendapat giliran pertama mengeluarkan kartu yang dapat dihubungkan dengan kartu kunci. Jika yang keluar sebagai kartu kunci adalah kartu model kedua, maka pemain harus dapat menghubungkan salah satu sisi kartu kunci dengan salah satu sisi kartu pemain. Kartu terus berjalan hingga seluruh kartu habis. Pada saat kartu dijatuhkan dan dihubungkan dengan salah satu sisi kartu yang sudah jatuh, maka pemain harus dapat menyerukan suku kata atau warna yang akan dipasangkan dengan suara keras. Maka teman yang sedang tidak bermain akan mengetahui, kartu "mana" dihubungkan dengan kartu "apa". Karena setiap kartu memiliki dua sisi, yaitu sisi kanan dan sisi kiri yang dapat saling dihubungkan dalam permainan ini. Terutama jika kartu sudah bergerak cukup panjang. Dengan demikian setiap peserta didik yang bermain kartu dapat saling mengamati pergerakan kartu-kartu yang sudah tersusun dalam permainan kartu domino.

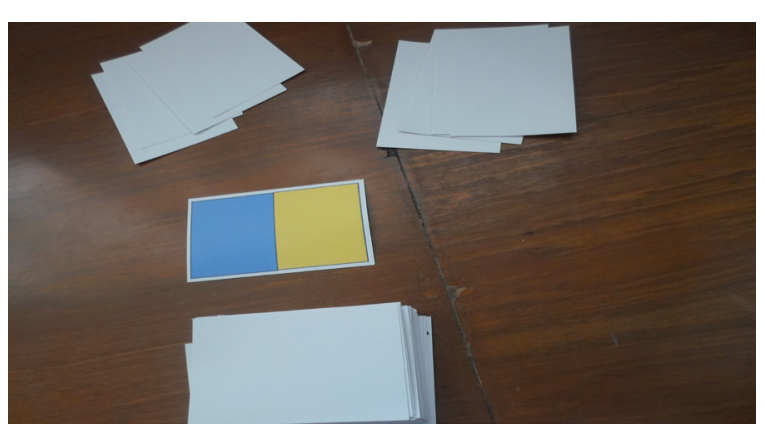

Gambar 2

Kartu Domino Suku Kata

Jurnal Penelitian Pendidikan 
Hipotesis yang dirumuskan dalam penelitian ini adalah: jika pembelajaran dilakukan dengan menerapkan modifikasi permainan kartu domino, maka kemampuan belajar membaca suku kata pada peserta didik tunagrahita sedang kelas VII di SLB Negeri Subang akan meningkat.

\section{METODE PENELITIAN}

Penelitian ini berbentuk penelitian tindakan kelas. Penelitian tindakan kelas merupakan suatu pencermatan terhadap kegiatan belajar berupa sebuah tindakan, yang sengaja dimunculkan dan terjadi dalam sebuah kelas secara bersama. Tindakan tersebut diberikan oleh guru atau dengan arahan dari guru yang dilakukan oleh peserta didik (Arikunto, Suharsimi, \& Suhardjono, 2010). Waktu penelitian pada semester II (dua) tahun ajaran 2015/2016 (6 Januari-30 Juni 2016). Bertempat di Ruang Kelas VII SMPLB-C1 SLB Negeri Subang Jalan Trubus Blok Sukaasih I Nomor: 36 Kecamatan Subang Kabupaten Subang. Subjek penelitian ada tiga orang peserta didik laki-laki dan satu peserta didik perempuan. Identitas dan kemapuan awalnya (tabel 1) adalah berikut ini.

\section{Tabel 1}

Kondisi Subjek Penelitian

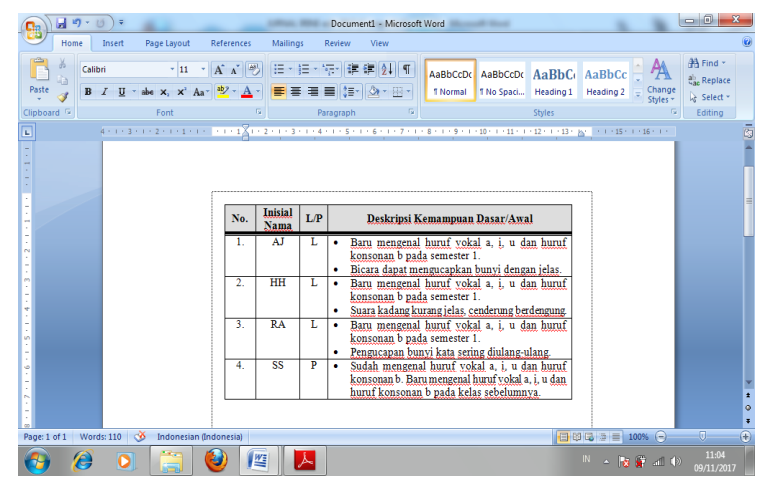

Prosedur tindakan dari penelitian ini menggunakan tiga siklus sebagaimana tampak pada gambar 3. Masing-masing siklus terdiri dari 4 tahap, kegiatan yang terencana, yaitu: menyusun rancangan tindakan (Planning), pelaksanaan tindakan (Acting), pengamatan
(Observing), dan refleksi (Reflecting).

1. Siklus I. Indikator keberhasilan pada siklus pertama ini adalah berikut ini.

a. Seluruh peserta didik dapat melaksanakan aktivitas pembelajaran menggunakan permainan Kartu Domino Suku Kata.

b. Empat peserta didik tunagrahita sedang kelas VII SMPLB-C1 dapat mengucapkan satu suku kata yang dijatuhkan oleh kartu domino.

c. Ada perubahan sikap peserta didik kelas VII SMPLB-C1 berkaitan dengan kemandirian dan ketertiban.

2. Siklus II. Indikator keberhasilan pada siklus kedua ini adalah berikut ini.

a. Seluruh peserta didik dapat melaksanakan aktivitas pembelajaran di kelas menggunakan permainan Kartu Domino Suku Kata.

b. Empat peserta didik tunagrahita sedang kelas VII SMPLB-C1 dapat mengucapkan satu suku kata yang dijatuhkan oleh kartu domino.

c. Ada perubahan sikap peserta didik yang sudah memahami pola permainan modifikasi kartu domino.

d. Ada perubahan sikap peserta didik kelas VII SMPLB-C1 berkaitan dengan kemandirian dan ketertiban.

3. Siklus III. Indikator keberhasilan pada siklus ketiga ini adalah berikut ini.

a. Seluruh peserta didik dapat melaksanakan aktivitas pembelajaran di kelas menggunakan permainan Kartu Domino Suku Kata.

b. Munculnya keceriaan dan kegembiraan saat bermain kartu domino.

c. Empat peserta didik tunagrahita sedang kelas VII SMPLB-C1 dapat mengucapkan dua suku kata yang dijatuhkan oleh kartu domino.

d. Ada perubahan sikap peserta 
didik yang sudah memahami pola permainan modifikasi kartu domino.

e. Ada perubahan sikap peserta didik di kelas VII SMPLB-C1 berkaitan dengan kemandirian dan ketertiban dalam permainan.

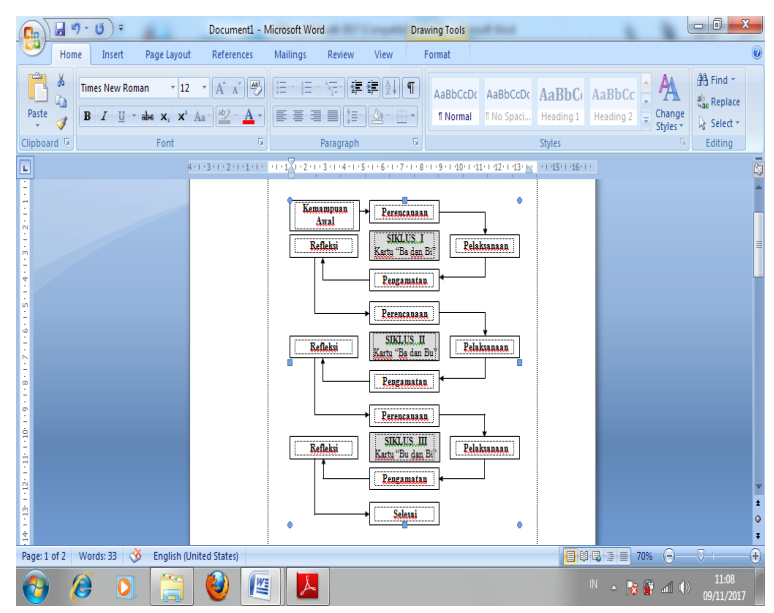

Gambar 3

Prosedur Siklus Tindakan

Teknik pengumpulan data dari penelitian tindakan kelas ini melalui observasi, melengkapi dokumen kegiatan (silabus, RPP, LKS, Tugas terstruktur, Catatan Kemajuan Belajar Peserta didik, catatan harian, dan Kumpulan Nilai), dan rekaman photo dari seluruh aktivitas pembelajaran.

Instrumen pengumpulan data dari penelitian tindakan kelas ini adalah: (a) Instrumen pengamatan peserta didik; (b) Instrumen pengamatan guru dalam KBM; dan (c) Format pengamatan proses belajar mengajar.

Analisis data dari penelitian tindakan kelas ini menggunakan langkah-langkah kegiatan reduksi data, paparan data berupa urutan dari semua data yang telah dipaparkan, dan penyimpulan, berupa pernyataan kalimat yang singkat dan padat tetapi mengandung pengertian yang luas.

\section{HASIL DAN PEMBAHASAN}

1. Hasil Siklus I. Kegiatan pembelajaran terencana pada siklus pertama dilaksanakan pada minggu ke-1 dan 2
Bulan Februari 2016 (3 dan 10 Februari 2016). Perolehan nilai hasil belajar membaca adalah pada tabel 2 dan gambar 4 berikut ini.

Tabel 2

Perolehan Nilai Hasil Belajar Siklus I

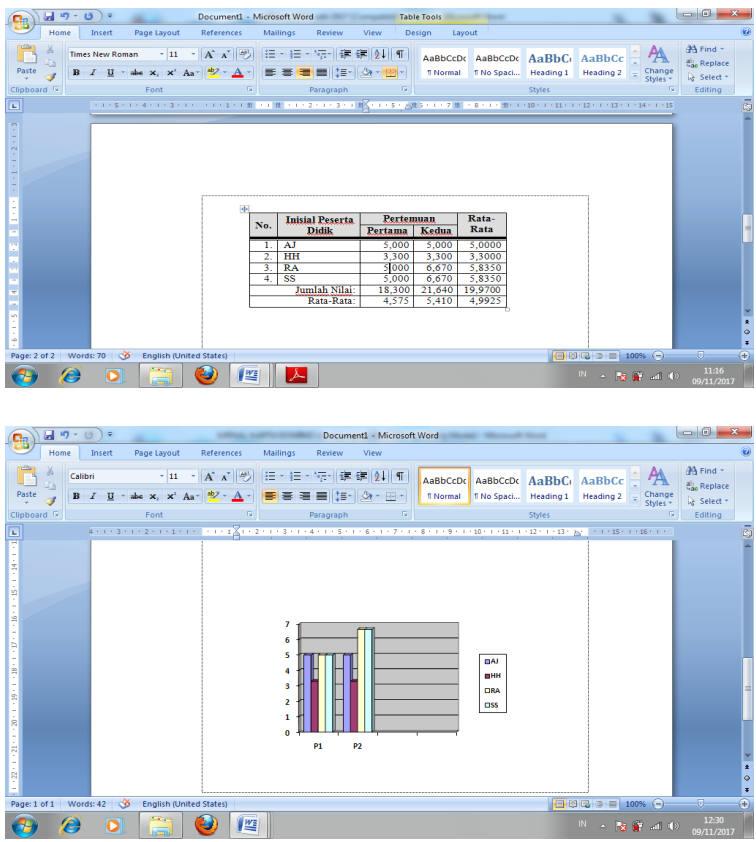

Gambar 4

Grafik Perolehan Nilai Hasil Belajar Siklus I

Kegiatan pembelajaran pada siklus I adalah siklus awal dalam menggunakan permainan kartu domino untuk membaca suku kata "ba dan bi". Hasil tertinggi diperoleh RA dan SS, sedangkan hasil terendah diperoleh HH. Pada siklus I juga teramati perubahan aktivitas belajar peserta didik sebagaimana tampak pada tabel 4 berikut ini. Kriteria penilaian sikap pada setiap siklus sebagaimana tampak pada tabel 3 .

Tabel 3

Kriteria Penilaian Sikap Belajar

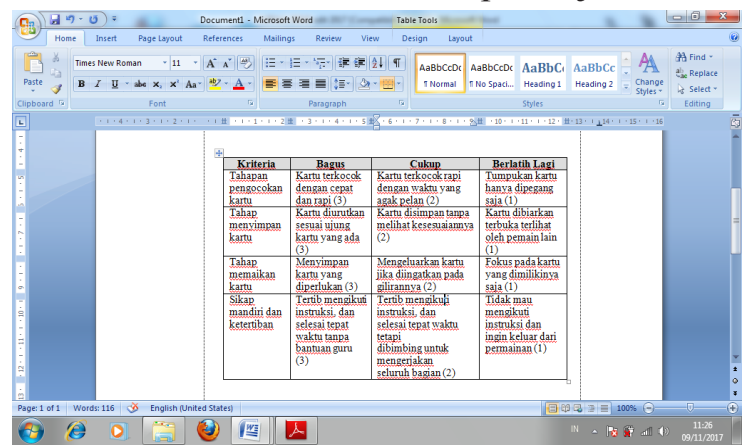

Jurnal Penelitian Pendidikan 
Tabel 4

Sikap Belajar Dalam Permainan Kartu Domino Suku Kata (Siklus I)

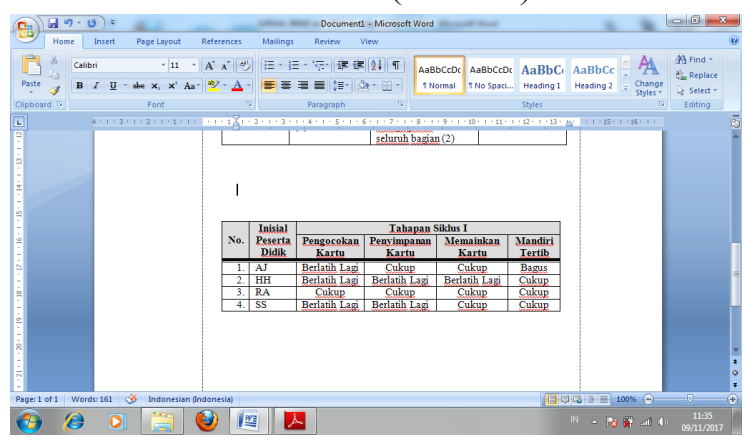

2. Hasil Siklus II. Kegiatan pembelajaran terencana pada siklus kedua dilaksanakan pada minggu ke-4 Bulan Februari dan Minggu ke-1 Bulan Maret 2016 (24 Februari dan 2 Maret 2016). Perolehan nilai hasil belajar membaca pada tabel 5 adalah berikut ini.

Tabel 5

Perolehan Nilai Hasil Belajar Siklus II

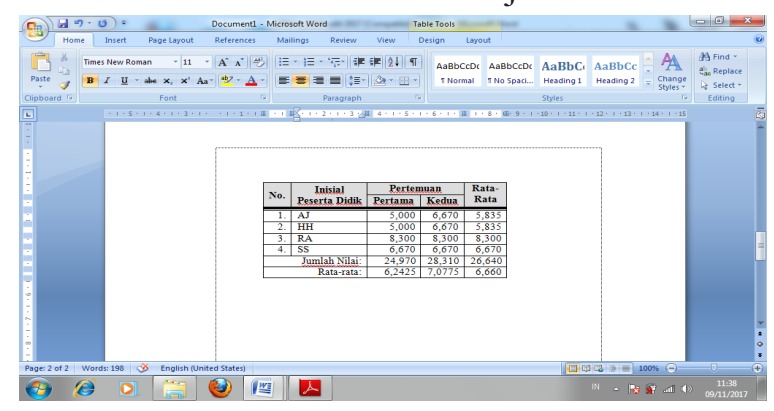

Kegiatan pembelajaran pada siklus II menggunakan permainan kartu domino untuk membaca suku kata "ba dan bu". Hasil tertinggi diperoleh RA, sedangkan hasil terendah diperoleh AJ dan HH. SS memiliki nilai yang stabil pada pertemuan pertama dan kedua. Grafik perolehan nilai pada siklus II tampak pada gambar 5 berikut ini.

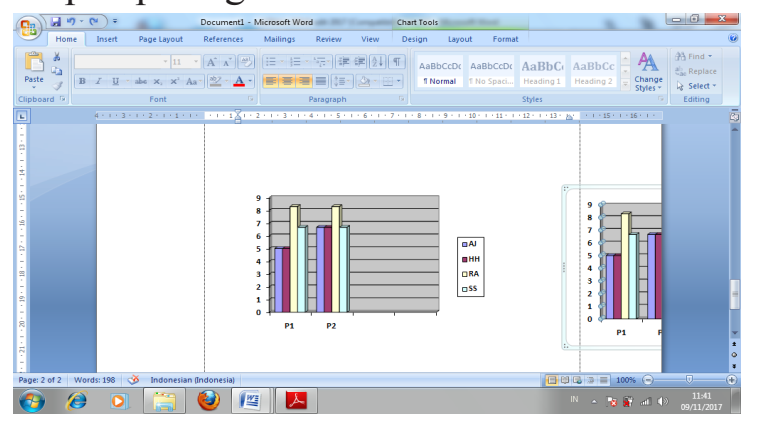

Gambar 5

Grafik Perolehan Nilai Hasil Belajar Siklus II
Pembelajaran pada siklus II juga dilakukan pengamatan terhadap perubahan sikap aktivitas belajar peserta didik dalam membaca menggunakan permainan Kartu Domino Suku Kata.

Tabel 6

Sikap Belajar Dalam Permainan Kartu Domino Suku Kata (Siklus II)

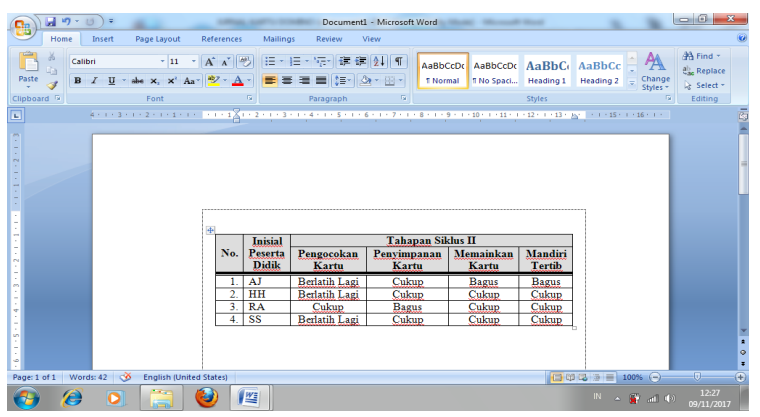

3. Hasil Siklus III. Kegiatan pembelajaran terencana pada siklus ketiga dilaksanakan pada minggu ke-4 dan 5 Bulan Maret 2016 (23 dan 30 Maret 2016). Perolehan nilai hasil belajar membaca pada pembelajaran pertama dan kedua sebagaimana tampak pada tabel 7 berikut ini.

Tabel 7

Perolehan Nilai Hasil Belajar Membaca Suku Kata Siklus III

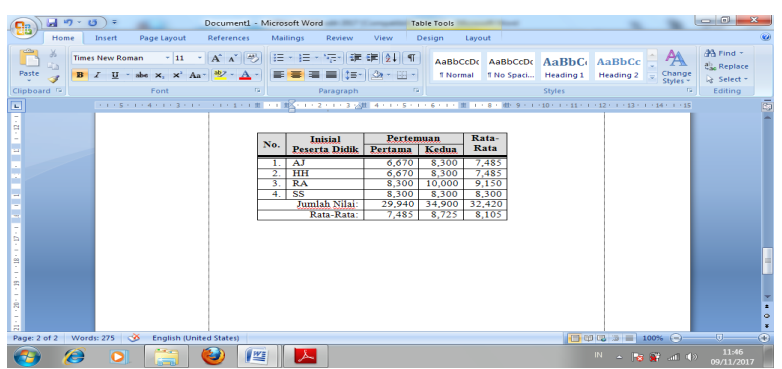

Grafik perolehan nilai belajar dari siklus III tampak pada gambar 6 .

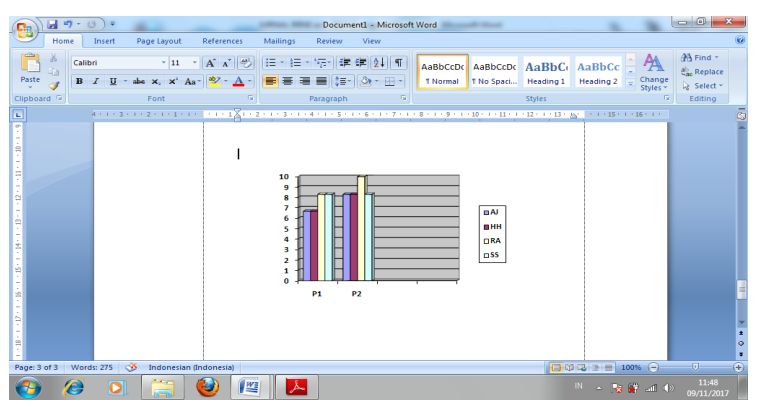

Gambar 6

Grafik Perolehan Nilai Hasil Belajar Siklus III 
Kegiatan pembelajaran pada siklus III (tabel 8) menggunakan permainan kartu domino dalam membaca suku kata "bu dan bi”. Hasil tertinggi diperoleh RA, sedangkan hasil terendah diperoleh AJ dan HH. Pada siklus ini juga teramati perubahan aktivitas belajar peserta didik.

Tabel 8

Sikap Belajar Dalam Permainan Kartu Domino Suku Kata (Siklus III)

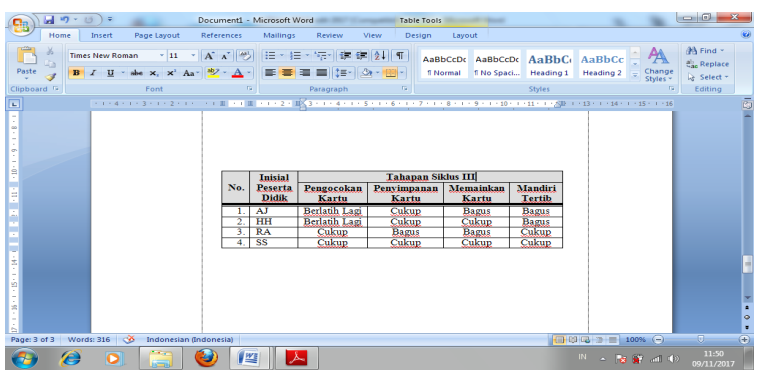

4. Perbandingan Tiga Siklus. Perolehan nilai hasil belajar membaca pada pembelajaran keseluruhan siklus sebagaimana tampak pada tabel 9.

Tabel 9

Perolehan Nilai Hasil Belajar Keseluruhan

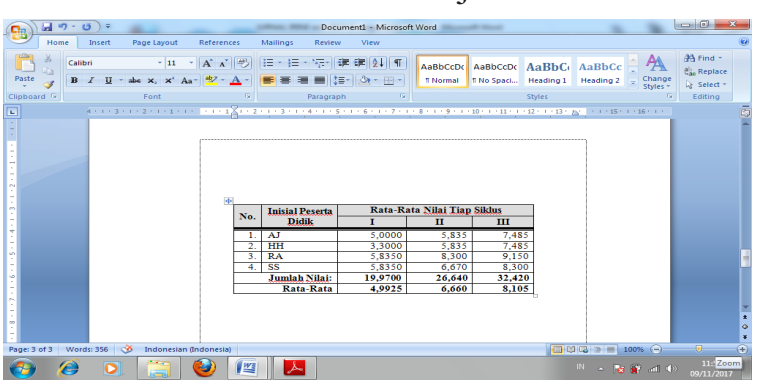

Grafik perolehan nilai belajar dari siklus I, II, dan III tampak pada gambar 7.

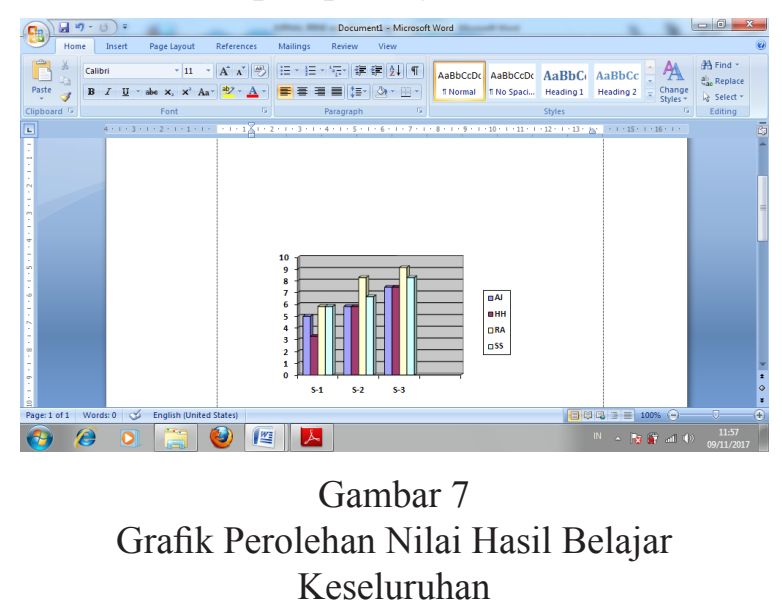

\section{PEMBAHASAN}

Siklus1 fokus kegiatan pembelajaran dan penelitian pada Siklus I pada tanggal 3 dan 10 Februari 2016. Permainan kartu domino yang digunakan adalah kartu domino untuk suku kata "ba" dan "bi". Ada dua warna (kartu warna biru dan kuning), serta dua suku kata yang digunakan. Setelah melaksanakan permainan, peserta didik dilihat perkembangan kemampuan membacanya. Juga diamati sikapnya selama melaksanakan permainan Kartu Domino Suku Kata. Perilaku yang tampak pada peserta didik dicatat. Hasilnya menjadi bahan pertimbangan pada siklus II. Penilaian sikap peserta didik saat melaksanakan pembelajaran menggunakan Kartu Domino Suku Kata menunjukkan bahwa ada perbedaan sikap peserta didik dalam belajar antara AJ, HH, RA, dan SS. AJ memiliki nilai baik dalam satu tahapan. HH harus banyak berlatih lagi bersama SS. RA memiliki nilai cukup dalam keseluruhan permainan.

Siklus II fokus kegiatan pembelajaran dan penelitian pada Siklus II pada tanggal 24 Februari dan 2 Maret 2016. Kartu domino yang digunakan adalah kartu domino untuk suku kata "ba" dan "bu". Ada dua warna (kartu warna biru dan merah), serta dua suku kata yang digunakan. Setelah melaksanakan permainan, peserta didik dilihat perkembangan kemampuan membacanya. Juga diamati sikapnya selama melaksanakan permainan Kartu Domino Suku Kata. Perilaku yang tampak pada peserta didik dicatat. Hasilnya menjadi bahan pertimbangan pada siklus III. Penilaian sikap peserta didik saat melaksanakan pembelajaran menggunakan Kartu Domino Suku Kata menunjukkan bahwa ada perbedaan sikap peserta didik dalam belajar antara AJ, HH, RA, dan SS. AJ 
memiliki dua nilai baik dalam dua tahapan. HH dan SS memiliki tiga nilai cukup untuk tiga tahapan. RA memiliki tiga nilai cukup dan satu nilai baik dalam keseluruhan tahapan.

Siklus III fokus kegiatan pembelajaran dan penelitian pada Siklus III pada tanggal 23 dan 30 Maret 2016. Kartu domino yang digunakan adalah kartu domino untuk suku kata "bu" dan "bi". Ada dua warna (kartu warna merah dan kuning), serta dua suku kata yang digunakan. Setelah melaksanakan permainan, peserta didik dilihat perkembangan kemampuan membacanya. Juga diamati sikapnya selama melaksanakan permainan Kartu Domino Suku Kata. Perilaku yang tampak pada peserta didik dicatat. Keseluruhan hasilnya dilihat dan dibandingkan antara kemampuan peserta didik satu dengan yang lainnya dalam membaca suku kata. Penilaian sikap peserta didik saat melaksanakan pembelajaran menggunakan Kartu Domino Suku Kata menunjukkan bahwa ada perbedaan sikap peserta didik dalam belajar antara $\mathrm{AJ}, \mathrm{HH}$, RA, dan SS. AJ sudah baik dalam dua tahapan. HH sudah bagus dalam kemandirian dan tertib. RA memiliki nilai baik dalam dua tahapan, sedangkan SS memiliki nilai cukup dalam keseluruhan permainan.

\section{SIMPULAN}

Ada perubahan sikap yang sangat positif dalam setiap kegiatan pada siklus I dan II. Aktivitas pembelajaran di kelas semakin bermakna menggunakan modifikasi permainan Kartu Domino Suku Kata. Walaupun dalam tahap pengocokan kartu, tiga peserta didik (AJ, HH, dan SS) harus berlatih lebih baik lagi, agar mampu mengocok kartu dengan baik. Beberapa tahapan sudah dapat diikuti peserta didik dengan nilai cukup. Perubahan terus meningkat antara hasil pada siklus I, II, dan III. Juga terdapat perubahan sikap dalam melaksanakan permainan Kartu Domino Suku Kata pada semua siklus. Ini menunjukkan bahwa permainan kartu domino suku kata dapat diikuti peserta didik tunagrahita sedang kelas VII SMPLB-C1 di SLB Negeri Subang.

\section{REKOMENDASI}

Dari hasil penelitian ini disarankan agar guru melakukan kegiatan berikut ini.

1. Guru melakukan kegiatan nyata dalam menerapkan pembelajaran agar mudah diingat peserta didik, terutama untuk anak tunagrahita sedang.

2. Guru membuat alat peraga atau alat permainan yang merangsang dan memiliki daya tarik yang tinggi.

3. Sekolah menyediakan anggaran khusus agar setiap guru terfasilitasi untuk membuat alat peraga yang unik.

\section{DAFTAR RUJUKAN}

Arikunto, Suharsimi, \& Suhardjono. (2010). Penelitian Tindakan Kelas. Jakarta: Bumi Aksara.

Astati, \& Lis, M. (2011). Pendidikan Anak Tunagrahita. Bandung: Amanah Offset.

Rahim, F. (2007). Pengajaran Membaca di Sekolah Dasar. Jakarta: Bumi Aksara.

Somantri, T. S. (2006). Psikologi Anak Luar Biasa. Bandung: Refika Aditama. 